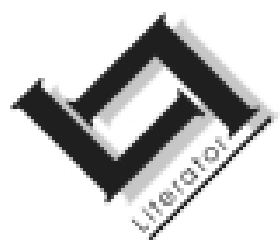

\title{
'n Ondersoek na die identifisering van deiktiese ruimte in die prosa
}

\author{
Johan Anker \\ Kaapse Technikon: Wellington-kampus \\ Fakulteit vir Onderwys \\ WELLINGTON \\ E-pos: ankerj@ctech.ac.za
}

\section{Abstract}

The role and function of deictic context in a prose text

This article examines the nature and function of deictics in a prose text. By referring to different theories of pragmatics and literature, the nature of communication in literary texts and the role that deixis plays in these texts become evident. In a prose text a process of communication exists in which the utterance produced by the speaker (author) is interpreted by a hearer (reader). The reader reconstructs a context for this communication by the interpretation of the speaker's references to person, place and time - the deictic elements.

The reader determines the deictic context in a text by defining and interpreting the communication of the abstract author, the different speaker's references to persons, space and time and by interpreting the implications in the linguistic utterance. In this way a deictic context is formed in the mind of the reader which forms the basis for his understanding of the message in the text.

\section{Opsomming}

'n Ondersoek na die identifisering van deiktiese ruimte in die prosa

Hierdie artikel ondersoek die aard en funksie van deiktiese elemente in 'n prosateks. Die rol wat deiksis in literêre tekste speel, word verduidelik met verwysing na veral teorieë uit die pragmatiek, literatuurteorie en die aard van kommunikasie in literêre tekste. Die kommunikasieproses in 'n prosateks bestaan uit 'n uiting deur die spreker (skrywer) wat geïnterpreteer word deur 'n hoorder (leser). Die leser konstrueer 'n konteks vir hierdie kommunikasie deur 'n interpretasie van die spreker se verwysing na persoon, plek en tyd-die elemente waaruit deiktiese verwysing bestaan. 
Die leser bepaal hierdie deiktiese konteks in 'n teks deur die spesifieke interpretasie van die kommunikasie deur die abstrakte outeur, die verskillende sprekers se verwysing na persoon, plek en tyd en deur die interpretasie van die implikasies in die taalaanbod. Op hierdie wyse word 'n deiktiese konteks deur die leser gevorm wat die basis word van sy begrip van die teks.

\section{Teks as kommunikasie}

Die doel van hierdie artikel is om aan te toon hoe die begrip van deiktiese elemente in 'n teks en die onderskeiding van 'n meer omvattende deiktiese ruimte kan bydra tot die interpretasie (lees) van 'n teks.

Verskeie teoretici het deur die jare al verwys na die literêre kommuniksieproses. Renkema (1993:90-93) neem die literêre genres sonder meer op in sy klassifikasie van diskoers en Roger Sell (1991:xiv) stel dit so:

Literary Pragmatics takes for granted that no communication in general will be complete without an account of literature and its contextualization, and that no account of literature will be complete without an account of its use of the communicative resources generally available.

Oor die belangrikheid van die taalhandelingsbenadering ten opsigte van die letterkunde, vergelyk C.H.F. Ohlhoff (1982:150-210) se proefskrif Taalkundige insigte en literêre tekste - veral die hoofstuk: "Pragmatiek en literatuur".

Binne die kommunikasiesituasie waarin die literêre teks geplaas word, het ons te doen met 'n pragmatiese situasie waarin veral die situasiekonteks beklemtoon word. Verskeie ondersoekers van die letterkunde en taalhandelingsteorie het juis die leser se begrip van hierdie situasiekonteks van die kommunikasie beklemtoon. Iser (1978:55) sê onder meer die volgende:

The speech act, as a unit of communication, must not only organize the signs but also condition the way in which these signs are to be received. They are linguistic utterances in a given situation or context, and it is through this context that they take on their meaning. (Vgl. ook Pratt, 1977; Van Dijk, 1976.)

Enkvist (in Sell,1991:10) sê oor die proses van kommunikasie: "we can interpret a text if we can build around it a world in which we recognize that the speaker or writer has conformed to acceptable maxims of communicative behaviour". Deur die literêre teks kom 'n pragmatiese 
situasie tot stand waarin verskeie kommunikasievlakke onderskei word, soos aangedui deur die resepsie-estetika (vgl. Van Coller \& Van Rensburg, 1983:113-115). Volgens Iser (1978:61) het fiksionele taal ook die basiese eienskappe van lokusie, illokusie en perlokusie en hou dit verband met die konvensies wat vir gewone gesprekke geld. Alhoewel die meeste van die sogenaamde gespreksvoorwaardes, soos deur H.P. Grice aangedui (Pratt, 1977; Lyons, 1979:593), oënskynlik in die letterkunde geïgnoreer word, stel Van Dijk (1976:49) dit duidelik dat die literêre werk slegs die gewone kommunikasieproses omkeer: die maksimumsamewerking word van die leser verwag om die gesprek te voltooi terwyl die outeur/spreker ongekende vryheid geniet ten opsigte van die normale gespreksvoorwaardes van waarheid, duidelikheid, relevansie en ekonomiese taalgebruik (vgl. ook Grundy, 1995:37 e.v.; Cruse, 2000: 355 e.v.).

Pratt (1977:203) erken hierdie afwykings van die normale gespreksvoorwaardes, maar skryf dit toe aan die implikasieverskynsel in die letterkunde:

I suggested that exploitation is virtually the only kind of intentional nonfullfillment of maxims that the literary speech situation allows, that intentional failure to fullfill a maxim in literature always counts as flouting and is thus always intended to be resolved by implicature.

Vanuit die relevansieteorie is daar heelwat kritiek uitgeoefen op die algemene aanvaarding van Grice se gespreksvoorwaardes. Pilkington (in Sell, 1991:50) verduidelik soos volg:

The key to pragmatic inferencing is the principle of relevance, which states that every act of inferential communication communicates a presumption of its own optimal relevance, i.e. a guarantee that the hearer will derive a satisfying range of cognitive effects for the minimum justifiable processing effort.

Cruse (2000:369) stel dat die relevansie van enige vorm van kommunikasie bepaal word deur die kontekstualisering daarvan en die prosessering van die inligting (vgl. ook Grundy, 1995:141 e.v.).

In aansluiting hierby redeneer Roger Sell (1991:215) dat die beleefdheidsbeginsel in kommunikasie Grice se koöperatiewe beginsel insluit: "I see all interaction, and all language, as operating within politeness parameters." Sternberg (in Sell, 1991:63) stel alle diskoers waarin gerapporteer word gelyk aan die reëls van diskoers oor die algemeen wanneer hy sê: "In a sense all reported discourse is a mimesis of discourse by discourse." 
Die belangrike rol van die leser in die kommunikasieproses word ook lank reeds beklemtoon. Iser (1978:66) stel dit duidelik dat die leser essensieel is vir die voltooiing van die potensiële betekenis van die literêre teks en sê verder dat hierdie lesersrol deur die teks self gekontroleer en beheer word (Iser, 1978:167-168). Verdonk (in Sell, 1991:96) stem daarmee saam:

... in literary pragmatic terms, the poet's text becomes a meaningful discourse only at the time when it is being read, that is, when the reader starts to build up interpersonal and socio-cultural contexts by imagining plausible cirumstances and motives which could have given rise to the discourse gradually taking shape.

Downing (2000:9) beklemtoon opnuut die aktiewe rol van die leser en die wisselwerking in die proses van diskoers tussen outeur, teks en leser.

\section{Konteks en deiksis}

Louis Marin sê in sy artikel "Toward a theory of reading in the visual arts" (1980:305) die volgende ten opsigte van deiksis:

Every linguistic utterance occurs in a determined spatio-temporal situation. It is produced by a person, the speaker (or sender) and addressed to another person (the hearer) who receives it. The deixis of an utterance is constituted by the orientational traits of language, traits related to the time, and the situation where the utterance takes place. In language, these traits are personal pronouns, whose meaning is defined by reference to the deictic coordinates of the typical situation where the utterance is emitted, as well as adverbs of time and place. Moreover we must notice that the typical situation of emission is egocentric, every linguistic exchange implying automatically the shift of the center of the deictic system when emission passes from one interlocuter to the other. Finally we may add that the deictic system expands to include demonstrative pronouns, verb tenses and ultimately frames the whole linguistic process ... a situation of communication implies that the linguistic system is actualized in a specific place and time, a place and a time that deictics refer to and whose structure is inscribed in the utterance (my kursivering - J.A.)

De Stadler (1989:378) sê deiktiese uitdrukkings "is die middele waarmee 'n uiting aan die gespreksituasie veranker word of met die situasie in verband gebring word".

Die term "deiksis" het in die oorspronklike Grieks beteken: om aan te dui, te wys. In die taalkunde word die term gebruik om veral die funksie van die persoonlike en aanwysende voornaamwoorde en aanduidings van 
tyd en plek aan te dui. Lyons (1979:637) gee die volgende definisie van deiksis:

By deixis is meant the location and identification of persons, objects, events, processes and activities being talked about, or referred to, in relation to the spatio-temporal context created and sustained by the act of utterance and the participation in it, typically of a single speaker and at least one addressee.

Lyons gaan dan voort om daarop te wys dat die normale gespreksituasie waarin die taaluiting gedoen word, altyd egosentries benader moet word in die sin dat die spreker die rol van die ego vervul en alle verwysings maak vanuit sy gesigspunt. Die spreker vorm dus die middelpunt of kern van waaruit die tydruimtelike konteks ontstaan, waarna verwys word as die deiktiese konteks. Hierdie egosentrisiteit van die spreker staan in die tydruimtelike kern - die hier en nou van die uiting (Lyons, 1979:638). De Stadler (1989:379) verwys na die sprekersrol as die "deiktiese sentrum".

Levinson (1983:63-64) brei veral uit oor die aspek van die egosentrisiteit van deiksis:

$\ldots$ it is generally true that deixis is organized in an egocentric way ... if we think of deictic expressions as anchored to specific points in the communitive event, then the unmarked anchorage points, constituting the deictic centre, are typically assumed to be as follows:

- the central person is the speaker,

- the central time is the time at which the speaker produces the utterance,

- the central place is the speaker's location at utterance time ...

- the discource centre is the point which the speaker is currently at in the production of his utterance, ...

- the social centre is the speaker's social status and rank.

Die deiktiese middelpunt kan egter ook verskuif na ander sprekers: “... ways that shift this deictic centre to other participants, or indeed to protagonists in narrative" (Levinson, 1983:64; vgl. ook Grundy, 1995:27, 34).

Cruse (2000:322-325) onderskei ook sosiale, diskoers-, gebare en simboliese deiksis wat aansluit by Levinson se uiteensetting (vgl. ook De Stadler, 1989:386 en Renkema, 1993:76-78).

Deiksis het dus direk te make met die totstandkoming van die konteks van die taalhandeling: "The single most obvious way in which the relationship between language and context is reflected in the structures 
of languages themselves, is through the phenomenon of deixis" (Levinson, 1983:54). Hy noem ook as voorbeelde die deiktiese elemente wat die situasiekonteks bepaal: die gebruik van aanwysende en persoonlike voornaamwoorde, tydsaanduidings, bywoorde van tyd en plek, en alle ander grammatikale elemente wat enigsins te doen het met die konteks van die taaluiting. Levinson (1983:54) verklaar verder:

Essentially, deixis concerns the ways in which languages encode or grammaticalize features of the context of utterance or speech event and thus also concern ways in which the interpretation of utterances depends on the analysis of that context of utterance.

Die belangrike aanname dat die interpretasie van 'n taaluiting afhang (bepaal word deur) van die analise van die deiktiese konteks waarin die uiting plaasvind, word ondersteun deur Lyons (1979:646) wanneer hy beweer dat deiksis beperkinge plaas op die moontlikheid van die dekontekstualisasie van 'n uiting. Lyons (1983:230) stel dit duidelik dat die konteks van 'n taaluiting uiters belangrik is vir die begrip van alle verwysings in 'n uiting. Hy noem die begrip "deiktiese konteks" 'n integrale deel van die konteks van taaluitings: "every act of utterance, every locutionary act occurs in a spatio-temporal context whose centre, or zeropoint, can be referred to as here-and-now". Carstens (1997:169) praat van deiktiese verwysings se funksie om die aangesprokene se aandag te vestig op iets of iemand wat ten opsigte van die ruimte of tyd geplaas kan word in die gemeenskaplike pragmatiese konteks.

Grundy (1995:30) brei veral uit oor die belangrike funksie wat deiksis vervul ten opsigte van die gedeelde verwysingsveld tussen spreker en hoorder/skrywer en leser. As sodanig het deiktiese verwysings in 'n teks 'n baie wyer funksie as net die beperkte bespreking van enkele woorde met spesifieke deiktiese betekenis. Volgens Grundy (1995:31) is die opbou van die hele konteks van 'n uiting en die verbinding tussen elemente waarna in die konteks verwys word, afhanklik van deiktiese elemente. So word aspekte van die kontekste van uitings geïntegreer met die grammatikale sisteem van die taal; aspekte wat weer deur die ontvanger en interpreteerder van die taal geprosesseer moet word. Grundy (1995:35) het die volgende te sê oor die belangrikheid van deiktiese verwysings in kommunikasie:

Indexicals, and deictic indexicals in particular are especially important to pragmaticists because they show how one kind of understanding, reference, is only possible when speaker and hearer share knowledge in common.

Deictics display the prototypical property of all pragmatic language use - that of relying on speaker-hearer subjectivity for their interpre- 
tation. In the case of deictics this is more evident than in any other category of pragmatic phenomena. Hence their importance.

(Die belangrikheid van anaforiese verwysings word nie hiermee ontken nie. Die deiktiese sisteem binnne die teks [deiktiese konteks] sluit die anaforiese verwysingsisteem in - vgl. Lyons, 1979:667-669 en De Stadler, 1989:423.)

\section{Die deiktiese ruimte}

\subsection{Deiktiese konteks in die literêre teks}

Die belangrikheid van 'n deiktiese konteks is eweseer van toepassing op 'n literêre teks waarin 'n konteks geskep word deur 'n spreker (verteller) wat 'n boodskap wil oordra aan 'n ontvanger (leser) en waar die leser, soos in alle ander skriftelike kommunikasie, die konteks alleen kan rekonstrueer uit die uiting, die taaltekens self, waarin hy dan afhanklik is van die spreker se verwysings na persoon, plek en tyd, dit wil sê die deiktiese elemente (Anker, 1987:16). Binne die literêre teks is dit dus die leser se taak om die verwysings na persone, gebeure, plekke en tye te identifiseer en te lokaliseer relatief tot die posisie van die egosentriese spreker (verteller of persoon).

Henning Snyman (1983:202) het reeds die begrip "deiktiese ruimte" ten opsigte van die poësie soos volg gedefinieer:

As die ruimte in die gedig 'n alliansie het met die implikasie, en die implikasie voortvloei uit die taalhandeling, dan beduie deiktiese ruimte, in navolging van Lyons, ongeveer dat in die gedig die verhouding tussen mens en ruimte resoneer in die verhouding van die taalmiddele tot die implikasie.

Volgens Snyman (1983 en 1986) kom die deiktiese ruimte in die gedig tot stand deur die verhouding en integrasie van deiktiese elemente en ruimtelike elemente aan die een kant en die implikasies in die taalaanbod aan die ander kant.

Ook ten opsigte van die drama is reeds verwys na die rol van deiksis deur Alessandro Serpieri en Keir Elam. Elam (1980:26, 27) beskryf deiksis as die belangrikste taalfaset van die drama omdat deiksis die spreker en hoorder in die gespreksituasie aandui, die tyd en plek van aksie aandui, die konteks skep en ook na voorwerpe in die konteks verwys. In die drama word die voorwerpe, gebeure, tyd en ruimte, selfs persone geskep deur 'n verwysing daarna in die sogenaamde "universe of discourse" (Elam, 1980:150, 151). 
Culler (1981:126) sluit hierby aan wanneer hy sê dat deiksis juis een van die elemente van die spraakhandeling is wat in die literêre teks verskil van die gewone spraaksituasie: "Obvious candidates are deictics - I, you, here, now, yesterday - which no longer take their meaning from a moment and situation of utterance but are devices which enable one to construct a fictive situation."

\subsection{Tekswêreld}

In hierdie opsig is die insigte van Paul Werth (soos bespreek in Downing, 2000 ) in verband met die skep van tekswêrelde baie belangrik. Downing (2000:13) sê dat die leser, terwyl hy lees, 'n tekswêreld binne of agter die teks aflei. In hierdie konstruksie van die konteks soos deur die teks geïmpliseer of aangedui, is die rol van sekere elemente soos deiktiese verwysings, agtergrondskennis en metaforiese taalgebruik essensieel. Sy haal Werth dan direk aan (Downing, 2000:13):

A text world, in particular, represents the principal state of affairs expressed in the discourse. First, the world must be defined; this is effected by means of the deictic and referential elements nominated in the text, and fleshed out from knowledge (specifically knowledge frames) ...

Werth (soos aangehaal deur Downing, 2000:83) verwys direk na die tekswêreld as 'n deiktiese ruimte: "... a text world is a deictic space, defined initially by the discourse itself, and spesifically by the deictic and referential element in it". Hy verwys ook na die diskoerswêreld wat tot stand kom tussen leser en outeur, maar verwys na die tekswêreld soos volg: "... the text world is identified deictically and displays a viewpoint the one of the speaker/writer - for the benefit of the interlocutor". Die aard van die definiëring van die tekswêreld beskou hy as: "... specifying the deictic information regarding entities and time and space coordinates. These are basic world-building elements".

\subsection{Implikasies in die literêre teks}

In verband met die implikasie binne die gespreksituasie en literêre teks as geheel beweer Searle (1979:74): “... any important work of fiction conveys a 'message'... which ... [is] conveyed in the text but ... [is] not in the text". In navolging van Grice se "conversational implicature" kom dit min of meer daarop neer dat ons met implikasie te doen het wanneer ' $n$ spreker A iets sê met die letterlike bedoeling $p 1$ en 'n hoorder B op grond van konteks en situasie ' $n$ interpretasie $p 2$ daarvan aflei wat meer en of anders is as p 1 (vgl. Ohlhoff, 1982:177). 
Wat die implikasieverskynsel betref, betrek heelwat teoretici Grice se gespreksvoorwaardes by die verduideliking van die verskynsel. Die argument kom daarop neer dat die normale gespreksvoorwaardes van opregtheid, relevansie, hoeveelheid en duidelikheid - in stryd met die verwagting en veronderstelling van die ontvanger - deur middel van implikasie weerspreek word, selfs opgehef word. Van Coller en Van Rensburg (in Van Coller \& Van Rensburg, 1984:87) verwys daarna dat hierdie afwyking of vervreemding juis 'n onderskeidende kenmerk van literêre werke is (vgl. ook Pratt, 1977:163).

In so 'n geval maak die spreker dan staat op die leser se gemeenskaplike agtergrondsinligting, linguisties en andersins, en die vermoë om logiese afleidings te maak en verwysings te herken (vgl. Searle, 1979: 32). Hierdie siening stem in 'n groot mate ooreen met die latere sieninge in verband met die relevansieteorie en die beleefdheidsbeginsel waarna vroeër verwys is (vgl. 1).

Du Plessis en Van Jaarsveld (1983:28) onderskei in hierdie verband tussen twee soorte implikasies, naamlik die semantiese of linguistiese en gespreksimplikasies. Die literêre werk as geheel dien dus as voorbeeld van 'n gespreksimplikasie wat deur die leser geïnterpreteer moet word om die teks tot stand te bring (Van Coller \& Van Rensburg, 1983:102).

\section{4 'n Deiktiese ruimte in die prosa}

In die prosateks kom daar myns insiens 'n deiktiese ruimte tot stand in die wisselwerking tussen outeursteks en leser, vertelteks en leser, en persoonsteks en leser binne die deiktiese verwysingsveld (deiktiese konteks) wat bestaan uit die verwysings na persoon, plek, en tyd binne die gekonstrueerde en gerekonstrueerde konteks. In die vormingsproses van hierdie tekswêreld word die geïmpliseerde boodskap oorgedra en deur 'n leser geïnterpreteer.

Tydens die analise van 'n literêre teks kan daar dus met vrug gebruik gemaak word van 'n ondersoek na die deiktiese ruimte van die teks wat sal bestaan uit die identifikasie en interpretasie van die volgende elemente:

- die outeursteks (titel, subtitel, motto ...)

- die vertelteks en persoonsteks se verwysings na persoon, plek, tyd, gebeure en voorwerpe

- die implikasies van die taalaanbod van die verskillende sprekers in die tekswêreld

- die boodskap van die teks as geheel 


\section{Die deiktiese ruimte in "Die gusooi"}

Vervolgens sal die deiktiese ruimte in die kortverhaal "Die gusooi", deur A.H. de Vries (1982:96-102) op hierdie wyse ondersoek word.

\subsection{Outeursteks}

In die gesprek tussen outeur en leser is die eerste vlak van kommunikasie dikwels die titel, subtitel en motto van 'n verhaal waarin die eerste intensie van die outeur ten opsigte van die boodskap wat hy wil oordra, deur die leser afgelees kan word (vgl. Van Coller \& Van Rensburg, 1983:104). In die eerste deel van die outeurskode, die titel, word reeds sekere betekenisverwagtinge geskep. Volgens die HAT verwys "gusooi" na 'n vroulike dier wat nie dragtig is nie, wat onvrugbaar of steriel is, nie kan aanteel nie. Dit word ook skertsend gesê van mense, veral 'n vrou wat ongetroud is of nie swanger is nie. In hierdie verhaal word die leser bewus van sowel die menslike as dierlike aspekte van hierdie betekenis soos die belewing van die vrou deur die persoonsteks algaande aan die leser bekendgestel word. Met die voltooiing van die leesproses, binne die konteks van die hele verhaal, word die betekenis van die titel vir die verhaal deur die leser tot stand gebring.

\subsection{Die vertelteks en persoonsteks se verwysing na spreker en persone}

Sowel De Stadler (1989:379) as Lyons (1979:638) beklemtoon dat enige gespreksituasie waarin taaluitings gedoen word, altyd egosentries benader moet word in die sin dat die spreker die rol van die ego vervul en alle verwysings maak vanuit sy standpunt. In navolging van Genette (1980: 186), Mieke Bal (1980:111-112) en Rimmon-Kenan (1983:74) word daar in 'n literêre teks 'n skerp onderskeid gemaak tussen die vertelinstansie en die fokalisator. Albei hierdie sprekerinstansies (vanuit die egosentriese benadering) kan teksintern en -ekstern optree in 'n teks. Hierdie sprekerinstansies bepaal vanuit sy/hul perspektief en posisie in die gesprekskonteks, asook op grond van sy/hul kennis en gebruik van die betrokke taalelement, watter verwysingswaarde die element sal hê (Carstens, 1997:168). In "Die gusooi" is die spreker 'n eksterne verteller wat die hele verhaal vertel vanuit een karakter, Klara, se waarneming, emosies en gedagtes: 'n eksterne verteller wat persoonsgebonde vertel (vgl. Bronzwaer, 1977:234). Bronswaer maak dan ook 'n duidelike verskil tussen vertelteks en persoonsteks.

Die egosentriese spreker in hierdie verhaal is dus 'n kombinasie van die eksterne vertelinstansie en Klara. Klara vorm die sentrale persoon ten opsigte van die verwysings na ruimte, tyd en gebeure, alhoewel haar 
ervarings, gesprekke en waarnemings deur die vertelinstansie, 'n personale verteller, verhaal word. Slegs in die beskrywing van die eerste paragraaf is die "sy" (Klara) afwesig - alhoewel dit ook haar ervaring sou kon wees:

Die louwarm noordwestewind wat elke middag opsteek, droog alles uit. Waarvandaan hy kom, weet niemand nie en waarom ook nie en min mense aanvaar hom in die lig van die geil jaar wat die hele aarde tot barstens toe volgemaak het. Selfs die hoek van die huis blaas net ' $n$ eentonige eenderse deun (p. 96) ${ }^{1}$

Die tyd en ruimte word wel egosentries waargeneem, dit wil sê deur die belewenis van ' $n$ bepaalde indiwidu op ' $n$ bepaalde punt in die tyd: die sentrale persoon is Klara, die sentrale tyd is haar tydsbelewenis en die sentrale ruimte is haar posisie vanwaar en waarbinne sy waarneem.

Die egosentriese spreker (en dus die deikties kern van waarneming) verskuif slegs wanneer Tinus in die direkte rede as spreker optree: "Sjoe, dit kook buite", en veral sy daaropvolgende woorde: "hierdie tyd van die jaar is dit beter om 'n gusooi te wees" (p. 96). Vanuit Tinus se belewenis "bedoel hy net wat hy sê en niks meer nie", deel die verteller ons mee. Dis egter duidelik dat Klara die uiting ook anders interpreteer, naamlik as 'n verwysing na haarself ('n duidelike verskil dus tussen lokusie, ilokusie en perlokusie). Die identifikasie van Klara met die gusooi blyk onder andere uit haar gedagtes (persoonsteks): "Die gusooie is 'gelukkig' het Tinus gesê. Het hy geweet van wie hy praat toe hy dit gesê het?" (p. 99) en: "Beter ja, maar as hierdie tyd van die jaar aanhou? As die lewe om haar kom en gaan en sy soos 'n eenkantboom staan en nooit vrugte dra nie?" (p. 100)

Ook Tinus se verwysing na die "geil jaar" omdat hulle 'n brief van die weeshuis gekry het in verband met ' $n$ aangenome kind, is 'n uiting uit sy belewing daarvan. Haar reaksie in haar gedagtes dui op 'n ander ervaring van die woorde; vir hom blydskap, vir haar bittere verwyt en frustrasie: “'”n Geil jaar' het hy gesê. Geil ja, maar op watter manier!" Trouens, so duidelik is die verskil in ervaring dat hy onmiddellik vra: "Is jy dan nie eers bly nie, Klaartjie?" (p. 98)

Ook die huishulp, Bollie, kry haar beurt as egosentriese spreker. Soos Tinus verwys ook sy na die vreugde van geboorte skenk: "... dis al die vierde maal m'vrou ... maar as hulle nie daar is nie mevrou, dan mis 'n mens elkene van hulle" (p. 100). Hierdie uiting kontrasteer sterk met

$1 \quad$ Bladsynommers verwys na De Vries (1982:96-102). 
Klara se posisie as onvrugbare en verskerp haar bitterheid teenoor die geil jaar en alles wat daarmee saamhang. Ook die verwysing na haar onbeholpenheid isoleer haar van die lewe om haar: "Mevrou het gevra wat sy moes doen, maar sy weet mos nou nog ook nie ..." (p. 100).

Die verskuiwing van egosentriese spreker het dus die funksie van kontrastering met die sentrale karakter se ervaring en belewenis en beeld uiteindelik die innerlike doodsheid by die vrou uit wanneer Tinus sê: "Die swartkop se lam lê dood."

\subsubsection{Die vertelteks en persoonsteks se verwysing na ruimte}

Deikties gesproke behels plek-deiksis die identifikasie en lokalisering van alle ruimtelike verwysings relatief tot die posisie en uitgangspunt van die spreker (Cruse, 2000:320-321; De Stadler, 1989:389; Grundy, 1995:23; Lyons, 1979:637; 1983:230; Levinson, 1983:64)

Weisgerber (1974:151-153) wys daarop dat ruimte in die prosa alleen binne en deur middel van taal bestaan ("een door woorden opgeroepen ruimten") en beklemtoon dit dat in die prosawêreld daar sprake is van 'n tydruimtelike milieu waar plek en tyd nie van handeling skeibaar is nie. Downing (2000:90) se uiteensetting van die skep van 'n tekswêreld waarin sy verduidelik hoe die deiktiese en referensiële elemente in die teks geïdentifiseer en deur die leser se agtergrondskennis geprosesseer word, is ook hier van toepassing (vgl. 3.2).

Literatuurteoretici is dit ook eens dat die beskrywing en totstandkoming van hierdie ruimte in die literêre teks bepaal word deur die egosentriese spreker: vertelinstansie en of fokalisator (vgl. Weisgerber, 1974:156 en Swanepoel, 1974:45-55). Soos Mieke Bal (1980:107) dit stel:

Zowel het personagebeeld als het beeld van de ruimte dat aan de lezer wordt aangeboden, wordt uiteindelijk bepaald door de wijze waarop personages en ruimte worden gezien. De vraag na wie ziet moet daarom als laatste aspect worden besproken.

Die betekenis van die titel in "Die gusooi" word reeds in die eerste paragraaf deur middel van ruimtelike verwysings in die vertelteks geïmpliseer met die kontras tussen die "louwarm westewind" wat alles uitdroog teenoor die "geil jaar wat die hele aarde tot barstens toe volgemaak het" (p. 96).

Juis hierdie teenstelling in die ruimte: die uitdroog "elke middag" teenoor die oorvloed van lewe in die "geil jaar" vorm die kern van die sentrale karakter se ervaring. Die volgende paragraaf stel reeds die binne teenoor buite, 'n verdere teenstelling in die ruimte: "Die lug in die voor- 
kamer is koeler" en Tinus sê: "dit kook buite" (p. 96), wanneer hy binnekom.

Die teenstellende verwysings na binne/buite sluit aan by die teenstelling droog (onvrugbaar-gusooi)/vrugbaarheid. Buite blêr die skape loom en tevrede, die wingerd is vol geswelde korrels, die skape lek die lammers aanhoudend, alles is dragtig. Binne is dit netjies, niks is uit hul plek nie, 'n koel en skoon stilte, "daar is iets onklaar in die huis" (p. 97). Tinus is gelukkig buite waar die skape lam; sy is ontevrede binne, ook haar gedagtes is buite, later "trek sy die gordyne oop" om buitentoe te kyk.

Die binêre opposisies van vrugbaarheid/onvrugbaarheid; tevrede/ontevrede, geluk/ongeluk word dus deur die ruimtelike verwysings ondersteun en versterk. Die uiterlike ruimte word beelddraer van die innerlike belewenis van die sentrale karakter. Dit is trouens opvallend hoe nie slegs Klara se innerlike belewenis nie, maar ook haar innerlike verandering ruimtelik uitgebeeld word. Aanvanklik praat sy van die "mooi jaar", later is alles vir haar "dragtig besmet" (p. 97). Wanneer sy buitentoe wil kyk, "is dit asof die wind iets in haar uitdroog". Die onbegrip van haar man word ook in terme van die ruimte ervaar: "Maar hy verstaan nie! 'n Geil jaar', het hy gesê. Geil, ja, maar op watter manier!" En nog later het sy die kombuisdeur toegemaak teen die "stemme van die pasgeborenes" (p. 98).

'n Verdere teenstelling in die ruimtelike verwysings word in die tweede deel van die verhaal gekoppel aan Klara se ervaring: die wingerd is donker van "volheid", die stoppelland daarteenoor, blink "leeg". Die belofte van die aangenome kind verskerp by haar die gevoel van leegheid want: "lewe kan nooit die plek inneem wat nooit anders as in die verbeelding gelewe het nie" (p. 99) - 'n verdere verwysing na die innerlike ruimte van die sentrale karakter.

Die derde ruimte, die huisie van haar huishulp, word ook teenstellend aangedui ten opsigte van haar huis. Dit is "karig gemeubileer', maar ironies met 'n vierde kind, teenoor Klara se vol gemeubileerde leë huis. Wanneer sy later wegvlug, is dit of selfs die ruimte met haar spot: alles is "tot barstens toe vol" en die kind se eerste skree is "asof dit agter die wind is (en) ... met haar spot" (p. 100). Die donkerte assosieer sy nou met vrugbaarheid: "Dis swart daar teen die kop ... soos die wingerde swart is" - "die lewe is daar vol en rooiryp". Daarteenoor brand die lig helder in haar huis, "hul eie huis en die stoppelland" (p. 100) word een in hul leegheid.

Haar gevoel van onvolkomenheid vergelyk sy met die ruimte van die warm, gesellige vertrek waar sy elke keer aankom "voor hulle die vuur 
aansteek". Ook in die slot van die verhaal verwys sy dan na die droë wind van die middag as oorsaak van die lam se dood en haar eie innerlike doodsheid, bevestig deur die doodmaak van die lam vroeër.

Die leser se interpretasie van die sentrale karakter se ervaring van die ruimte en die ruimtebeskrywing vanuit haar ervaring dra dus by tot die herkenning van basiese teenstellings in die verhaal, haar gemoedstoestand, haar verandering en uiteindelik die implikasies van die titel en tema.

\subsubsection{Die vertelteks en persoonsteks se verwysings na tyd}

Ook in die verwysing na tyd in die prosa is die posisie van die egosentriese spreker van belang. Alhoewel in die literêre teks die sogenaamde tyd van uiting en tyd van resepsie nie ooreenstem soos in die peroon-tot-persoondiskoers van elke dag nie, stem literatuurteoretici soos Bal (1980:65) en Genette (1980:40) daaroor saam dat tydsaanduidings vanuit die hier-en-nou van die spreker benader moet word. Venter (1982:218) gaan ook in sy onderskeiding tussen storietyd en vertellerstyd uit van die standpunt dat die egosentriese spreker se tyd van uiting in die prosateks as kernpunt van verwysing dien. Grundy (1995:33) verwys wel na die verskillende tye wat, deikties gesproke, voorkom tussen die tyd van uiting van die abstrakte outeur, die tyd waarin die teks deur die werklike leser gelees word en die tyd van uiting deur die persoon in die teks - vertelteks en persoonsteks.

Botha $(1990: 104,105)$ wys daarop dat daar in geskrewe kommunikasie 'n lang onderbreking kan wees tussen die enkodering en die dekodering van die boodskap. Die leser moet hom dan verplaas na die enkoderingstyd en hom vereenselwig met die kodifiseringstyd van die taaluiting. Op hierdie wyse is kodifiseringstyd dan die oomblik waarop die leser die tydsverwysings van die spreker vanuit die spreker se deiktiese sentrum interpreteer.

Die vertelinstansie, Klara en Tinus, verwys in woord of gedagtes na die "geil jaar". Klara verwys aanvanklik daarna as 'n "mooi jaar", en dink: "die jaar was dragtig tot dusver" (p. 96). Die vrugbaarheid in die natuur word dus met tyd verbind - die tyd waarin hierdie sprekers vertel, praat en dink, is geil en dragtig. (Cruse, 2000:325 verwys na hierdie soort tydsverwysing as simboliese deiksis.) Dit het egter teenstellende reaksies tot gevolg. By Tinus geluk, by Klara word alles langsamerhand "dragtig besmet" en daar groei 'n verset teen die "geil jaar" waarin sy so intens bewus gemaak word van haar onvrugbaarheid. Tinus se verwysing na die gusooie wat "hierdie tyd van die jaar" gelukkig is, het ook die teenoorgestelde reaksie by Klara tot gevolg, want sy vrees die gedurige 
bewus-wees van die vrugbaarheid om haar terwyl sy 'n "gusooi" en "eenkantboom" bly: "... maar as hierdie tyd van die jaar aanhou ... en sy nooit vrugte dra nie?" (p. 100).

Die tydsverwysing sluit ook die verlede in: "Hulle is al drie jaar getroud" juis daarom die gemis by die vrou en nog die hoop vir die toekoms: "... omdat sy lewe met die jong hoop in haar" (p. 98). Juis hierdie hoop word egter vernietig deur die bewus-wees van die voldrae lewe om haar. Die teenstelling in die verwysing na Bollie se tyd wat amper daar is en die vervulling van die tyd by Bollie verhoog haar eie wanhoop en frustrasie: "En die vrou is daar vol en rooiryp ... maar in hul eie woning brand die lig helder" (p. 100).

Die verwysing na hulle tyd, die volgende maand met die aangenome kind, is vir haar egter geen vervulling nie, slegs 'n bevestiging van eie onvermoë. Uiteindelik ervaar sy alleen 'n doodsheid: “... maar iets soos dun glas het ingeskuif tussen haar en die lewe in haar arms" (p. 101) "en die gevoel wat sy eers gehad het wanneer Tinus een van die lammers huis toe bring ... het verdwyn ... In die plek daarvan het iets kouds gekom, koud en bereken, amper sonder gevoel" (p. 101).

Die leser se identifisering en interpretasie van hierdie tydsverwysings vorm deel van die opbou van 'n deiktiese ruimte waarbinne ruimte en tyd deel word van die persoons- en lesersbelewing van die teks en die latere interpretasie van die teks as geheel.

\subsubsection{Die implikasies van die taalaanbod in die vertelteks en personeteks}

Die implikasies en beeldgebruik in die verhaal is ten nouste gekoppel aan die ervaring van die egosentriese spreker: vertelinstansie of karakter se waarneming van die voorwerpe en gebeure. Juis omdat dit vanuit die ervaring van die egosentriese spreker beskryf word, word sekere afleidings omtrent die persoon gemaak.

'n Belangrike element van die deiktiese ruimte is die leser se interpretasie van die implikasies in die taalgebruik en spesifiek metaforiese taalgebruik in die verhaal. Die basiese beeld is die identifikasie tussen die vrou en die gusooi - "Die gusooie is gelukkig, het Tinus gesê. Het hy geweet van wie hy praat toe hy dit gesê het?"(p. 99).

Die ander beelde in hierdie verhaal sluit direk aan by hierdie ervaring van die vrou: die bewuswording van haar eie onvolkomenheid teenoor die lewe daarbuite: die foto van Tinus wat "oopbek soos 'n lam wat melk soek op 'n kruiwa sit" (p. 97), sit sy weg; die personifikasie: "die jaar was 
dragtig", die wingerde en klaargeoeste "lande wat vredig" lê. Die gevoel van onvervuldheid blyk verder duidelik uit die vergelyking: "sy soos 'n eenkantboom staan en nooit vrugte dra nie" en "die wind hier teen haar moet aanwaai soos teen die stoppelland". Haar latere gevoelloosheid en koudheid blyk reeds uit die woorde "die vee soos bondels sneeu" en dan: "iets soos dun glas het ingeskuif tussen haar en die lewe in haar arms" (p. 101).

Die koms van die aangenome kind bied geen oplossing nie, want: "Dit sal iemand anders wees wat geboorte geskenk het aan hom. Soos die skape hier aan die lammers, soos die vrou daar bo in die huis met haar vierde kind" (p. 101). Die vervulling sal sy nooit smaak nie, want "sy sal dit kry wanneer dit klaar is. Soos een van die lammers waarmee Tinus inkom as die ooi nie melk het nie, en wat sy moet grootmaak" (p. 101).

Ook die wind wat aan die begin alles uitdroog, word beeld van hierdie ervaring by die vrou: "dis asof die wind iets in haar uitdroog", dis asof die lewe "agter die wind is wat skielik weer haar rok teen haar vaswaai, asof dit met haar spot", die wind wat "teen haar moet aanwaai soos teen die stoppelland" sodat haar slotwoorde baie meer impliseer as slegs die wind wat die lammers droogwaai. Sy het immers die lam doodgemaak en daarmee saam die hoop ook in haar drooggewaai.

Die toenemende obsessie en selfs waansin by die vrou word ook deur middel van taalimplikasies oorgedra. Daar is 'n duidelike progressie in frustrasie en toenemend irrasionele denke by die vrou: sy wens haar man wil mors op die mat (p. 96), dink "wrang" oor voortplanting (p. 97), raak al hoe meer impulsief in haar optrede waaroor sy later spyt is (p. 97), begin die donker assosieer met vrugbaarheid en blink met doodsheid (p. 98), wil uitskree in Tinus se gesig (p. 98), maak die venster toe teen die geluid van die pasgeborenes (p. 98), voel koud en leeg (p. 100), erken 'n voos kol in haar samestelling (p. 100), voel dat die kind se geboorteskree met haar spot (p. 100), voel iets kouds en bereken in haar opkom (p. 101), vloek en herhaal die vloek (p.101), voel 'n teengevoel in haar opbou (p. 101) en maak die lam dood (p. 101). Uiteindelik bly dan net "'n moeë gevoel in haar, asof alles wat rukkerig gelewe het, skielik weggevloei het" (p. 102).

\subsubsection{Die boodskap van die teks}

Die leser se integrasie van die deiktiese ruimte in die teks deur middel van die identifisering en interpretasie van die outeursteks, die vertelteks en persoonsteks se verwysings na persoon, plek en tyd en die taalimplikasies in die teks, kan myns insiens lei tot 'n begrip van die teks as 
geheel. Dit is volgens Grundy (1995:34) juis die rol wat deiksis kan speel in die interpretasie van 'n teks:

Crucially, the references effected (i.e. persons, place and time) can only be understood by an addressee who is able to reconstruct the speaker's viewpoint. When his reconstruction occurs, we have called the intersubjectivity attained 'common ground' or, in the earlier pages of the chapter, 'context'. Pragmatics is precisely about accounting for the ability of speakers and addressees to invoke a common context in relation to which a very wide range of language uses can be interpreted. This kind of interpretation is necessary because basic literal meanings are radically undetermined.

\section{Slot}

Hierdie artikel toon aan dat 'n deiktiese ruimte, soos afgelei uit beginsels van die semantiek en pragmatiek, direk aansluit by die kommunikasiesituasie wat deur 'n prosateks geskep word en deur die lees van die teks tot stand gebring word.

Die identifisering van 'n deiktiese ruimte in 'n prosateks is die onderskeiding van 'n geïntegreerde en samehangende deiktiese konteks bestaande uit basiese deiktiese gesprekselemente soos die identifikasie van 'n spreker en dié spreker se verwysing na persone, 'n tydruimtelike konteks, gebeure en voorwerpe asook die implikasies van die uiting/ taalaanbod van dié spreker.

Dit is juis wanneer die leser die elemente van die deiktiese ruimte en die samehang daarvan in die teks identifiseer en tot stand bring dat hy by die literêre kommunikasieproses betrek word en in die voltooiing daarvan 'n interpretasie van die geïmpliseerde boodskap in die teks kan formuleer.

\section{Bibliografie}

Anker, J. 1987. Die deiktiese ruimte as struktuurmiddel in die Afrikaanse prosa. Kaapstad : U.K. ( Ph.D.-proefskrif.)

Bal, Mieke. 1980. De theorie van vertellen en verhalen. Inleiding in de narratologie. Tweede, hersiene uitgawe. Muiderberg : Coutinho.

Botha, W.J. 1990. Deiktiese tydsverwysing. Acta Academia, 22(3):102-115.

Bronzwaer, W.J.M. 1977. Over het lezen van narratiewe teksten. In: Bronzwaer, W.J.M. e.a. Tekstboek Algemene Literatuurwetenschap. Baarn : Ambo: Basisboeken. p. 229-253.

Carstens, W.A.M. 1997. Afrikaanse tekslinguistiek. 'n Inleiding. Pretoria : Van Schaik.

Cruse, Alan. 2000. Meaning in language. An introduction to semantics and pragmatics. New York : Oxford University Press.

Culler, J. 1981. The pursuit of signs. Semiotics, literature, deconstruction. London : Routledge \& Kegan Paul. 
De Stadler, L.G. 1989. Afrikaanse sematiek. Johannesburg : Southern Boekuitgewers.

De Vries, A.H. 1982. "Die gusooi”. In: De Vries, A. H. Die Afrikaanse kortverhaalboek. Tweede uitgawe. Tweede druk. Kaapstad : Human \& Rousseau. p. 96-102.

Downing, L. H. 2000. Negation, text worlds and discourse. The pragmatics of fiction. Stanford : Ablex.

Du Plessis, L.T. \& Van Jaarsveld, G.J. 1984. Oor narre, grappies en kaal keisers: aspekte van die taalgebruik van die Nar in Die Keiser. In: Van Coller, H.P. \& Van Jaarsveld, G.J. (reds.) Taalhandelinge en letterkunde. Durban : Butterworth. p. 22-35.

Elam, Keir. 1980. The semiotics of theatre and drama. New Accents London : Methuen.

Genette, Gerard. 1980. Narrative discourse. Translated by J.E. Levin. Oxford : Blackwell.

Grundy, Peter. 1995. Literary pragmatics. London : Arnold.

Iser, Wolfgang. 1978. The act of reading. A theory of aesthetic response. London : Routledge \& Kegan Paul.

Levinson, S.C. 1983. Pragmatics. Cambridge : Cambridge University Press.

Lyons, John. 1979. Semantics. Vol. 2. Cambridge : Cambridge University Press.

Lyons, John. 1983. Language, meaning and context. Second impression. Bungary, Suffolk : Fontana Paperbacks.

Marin, Louis. 1980. Toward a theory of reading in the visual arts. In: Suleimann, S.R. (ed.) The reader in the text. Essays on audience and interpretation. Princeton: Princeton University Press. p. 292-324.

Ohlhoff, C.H.F. 1982. Taalkundige insigte en literêre tekste. Pretoria : U.P. (D.Litt.proefskrif.)

Pratt, Mary Louise. 1977. Towards a speech act theory of literary discourse. Indiana : Indiana University Press.

Renkema, Jan. 1993. Discourse studies. An introductory textbook. Amsterdam : Benjamin.

Rimmon-Kenan, Shlomith. 1983. Narrative fiction. Contemporary poetics. New Accents. London : Methuen.

Searle, J.R. 1979. Expression and meaning. Studies in the theory of speach acts. New York : Cambridge University Press.

Sell, Roger D. (ed.) 1991. Literary pragmatics. London : Routledge.

Snyman, Henning. 1983. Mirakel en muse. 'n Studie oor die funksie van die implikasie-verskynsel by die interpretasie van 'n gedig. Kaapstad : Perskor.

Snyman, Henning. 1986. Bontekoe: plek, tyd en persoon word een. In: Senekal, J. (red.) Teks-leser-konteks. Johannesburg : Perskor. p. 1-11.

Swanepoel, P.H. 1974. Ruimte as struktuurelement in die prosa van Etienne Leroux. Potchefstroom : PU vir CHO. ( D.Litt. - proefskrif.)

Van Coller, H.P. \& Van Rensburg, G.C.J. 1984. Suggesties, implikasies en afledings. In: Van Coller, H.P. \& Van Rensburg, G.J. (red.) Woorde as dade. Taalhandelinge en letterkunde. Durban : Butterworth. p. 86-98.

Van Coller, H.P. \& Van Rensburg, M.C.J. 1983. Appèlfunksies van literêre werke. In: Malan, C. (red.) Letterkunde en leser. 'n Inleiding tot lesersgerigte literêre ondersoek. Durban : Butterworth. (Sensal-publikasies nr. 4.) p. 94-112.

Van Dijk, T.A. 1976. Pragmatics of language and literature. Vol 2. Amsterdam : North Holland. 
Venter, L.S. 1982. Ruimte as epiese kategorie. 'n Ondersoek aan die hand van Afrikaanse en Nederlandse romans. Potchefstroom : PU vir CHO. (D.Litt. proefskrif.)

Weisgerber, J. 1974. Proefvlucht in de romanruimte. Amsterdam : Athenaeum.

\section{Kernbegrippe:}

De Vries, A.H. "Die gusooi"

deiksis

deiktiese konteks

deiktiese ruimte in die prosa

tekswêreld

\section{Key concepts:}

De Vries, A.H. "Die gusooi"

deixis

deictic context

deictic context as structure in prose

text world 
